\title{
PERANAN APARAT PENEGAK HUKUM DALAM PELANGGULANGAN TERORISME DI INDONESIA
}

\author{
Wahyu Wiriadinata
}

\begin{abstract}
The genuine goal of law is to achieve justice. For the achievement of justice in a community, an order should firstly be created. Disorder and chaos may be resulted from terrorism movement. Currently, terrorism movement in Indonesia is increasing, both in frequency and in acceleration. In fact, there is already a legislation that provides for the eradication of terrorism crime, i.e. Law Number 15 of 2003. The Law has been in effect since 2003 and implemented by Indonesia law enforcers, particularly Indonesia Police. However, due to some psychological constraints and juridical techniques, the handling of terrorism crimes has not been successful optimally. In general, the role of law enforcers has not been effective and optimal yet in preventing terrorism in Indonesia, because terrorism movements are not only local movements but also international networks by employing high technology, and terrorism movement in Indonesia is based on a fundamental ideology, that is, Islam. Therefore, it couldn't be approached by a repressive paradigm and juridical approach, but rather it should be supplemented by a psychological and sociological-religious approach. The method of research used was a juridical-normative method, and it was written by a descriptive-analytical method. The objective of this paper was as a contribution to legal science and public at large.
\end{abstract}

Keywords: terrorism, law enforcers, suboptimal

\begin{abstract}
Abstrak
Tujuan asli dari hukum adalah untuk mencapai keadilan. Untuk pencapaian keadilan di masyarakat, order terlebih dahulu harus dibuat. Gangguan dan kekacauan dapat dihasilkan dari gerakan terorisme. Saat ini, gerakan terorisme di Indonesia meningkat, baik dalam frekuensi dan akselerasi. Bahkan, sudah ada undang-undang yang menyediakan untuk pemberantasan kejahatan terorisme, yaitu Undang-Undang Nomor 15 Tahun 2003. UU telah berlaku sejak 2003 dan dilaksanakan oleh penegak hukum Indonesia, khususnya Kepolisian Indonesia. Namun, karena beberapa kendala psikologis dan teknik yuridis, penanganan kejahatan terorisme belum berhasil secara optimal. Secara umum, peran penegak hukum belum efektif dan optimal belum dalam mencegah terorisme di Indonesia, karena gerakan terorisme tidak hanya gerakan lokal tapi juga jaringan internasional dengan menggunakan teknologi tinggi, dan gerakan terorisme di Indonesia didasarkan pada ideologi fundamental, yaitu, Islam. Oleh karena itu, tidak bisa didekati oleh paradigma represif dan pendekatan yuridis, melainkan harus dilengkapi dengan pendekatan psikologis dan sosiologis-agama. Metode penelitian yang
\end{abstract}


digunakan adalah metode yuridis normatif, dan itu ditulis oleh seorang metode deskriptif-analitis. Tujuan dari makalah ini adalah sebagai kontribusi untuk ilmu hukum dan masyarakat luas.

Kata kunci: terorisme, aparat penegak hukum, tidak optimal

\section{Pendahuluan}

Aliran hukum alam atau hukum kodrat sebagaimana diutarakan oleh Aristoteles murid Socrates $( \pm 300$ tahun SM), memberikan arahan tentang tujuan hukum. Bahwa tujuan hukum yang utama adalah untuk mencapai tujuan akhir yang hakiki di masyarakat, yaitu tercapainya keadilan. Akan tetapi untuk mencapai keadilan dimaksud harus terlebih dahulu terciptanya ketertiban di masyarakat. Tanpa ketertiban tidak mungkin tercapai rasa keadilan di masyarakat.

Memang tujuan hukum bukan hanya untuk mencapai keadilan, tapi tujuan hukum adalah untuk adanya kepastian hukum, sebagaimana dianut oleh recht positivisme atau aliran hukum positif yang berkembang pada abad 19 dengan tokoh yang terkemuka yaitu Hans Kelsen (1881 - 1973). Akan tetapi tujuan hukum untuk mencapai keadilan di masyarakat merupakan tujuan hukum yang utama dan yang paling tua yang sampai saat ini tetap dipertahankan. Namun dengan syarat bahwa di masyarakat harus terlebih dahulu terciptanya ketertiban.

Tentang hal tersebut di atas dikemukakan juga oleh Muchtar Kusumaatmadja yang memberikan definisi tentang hukum, yaitu:

Hukum adalah keseluruhan asas dan kaidah yang mengatur pergaulan hidup manusia dalam masyarakat yang bertujuan untuk memelihara ketertiban dan mencapai keadilan, juga meliputi lembaga serta proses yang mewujudkan berlakunya kaidah tersebut sebagai kenyataan di masyarakat. ${ }^{1}$

Dari definisi yang dikemukakan tersebut di atas, jelaskan bahwa menurut Muchtar Kusumaatmadja tujuan hukum yang hakiki ialah terpeliharanya ketertiban dan tercapainya keadilan. Untuk tercapainya keadilan maka ketertiban harus tercipta terlebih dahulu. Tidak boleh ada kekacauan apalagi chaos serta kegiatan teror dan terorisme, dimana terorisme sudah pasti akan menimbulkan ketidaktertiban. Oleh karena itu untuk membebaskan masyarakat dari suasana teror dan menciptakan ketertiban, maka gerakan teroris harus dicegah dan diberantas.

Perihal eksistensi teror dan terorisme di Indonesia diawali oleh suatu nuansa yang terbangun ketika penjajah Belanda yang membonceng tentara

${ }^{2}$ P. Sitorus, Pengantar Ilmu Hukum (Dilengkapi Tanya Jawab)", Pasundan Law Faculty, (Bandung: Alumnus Press, 1998), hal. 94. 
sekutu mendarat di Indonesia pada Perang Dunia II, menyebut para pejuang kemerdekaan Indonesia dengan sebutan teroris atau extrimis. ${ }^{3}$ Demikianlah sejak itu istilah teroris diberikan kepada sekelompok orang atau suatu komunitas yang melakukan perlawanan dan perjuangan dengan cara kekerasan phisik khususnya dengan senjata.

Setelah Indonesia memproklamasikan kemerdekaan, sebagai negara merdeka yang berdaulat, istilah teroris tetap digunakan bagi kelompok atau komunitas bersenjata, yang melakukan perlawanan bersenjata.

Ketika terjadi peristiwa APRA (Angkatan Perang Ratu Adil) di Bandung pada 23 Januari 1950). Peristiwa itu dipimpin oleh seorang Kapten KNIL (Koninglijke Nederlands Indicshe Lagger), yaitu Kapten Raymond Westerling, pemerintah Indonesia menyebut peristiwa itu sebagai teror yang dilakukan oleh Belanda. Dimana pada tanggal 23 Januari 1950 pagi-pagi sekitar 800 serdadu KNIL dengan berjalan kaki dari Cimahi menuju Bandung, sepanjang jalan melakukan penembakan terhadap tentara R.I sehingga menimbulkan puluhan tentara R.I. dari divisi Siliwangi gugur, termasuk Kolonel Lembong. Sebelumnyapun pada Desember 1946, Kapten Raymond Westerling telah mengkomando dan memimpin pembantaian 40.000 rakyat Sulawesi Selatan, peristiwa ini dinamakan teror di Sulawesi Selatan. Kemudian tindakan teroris juga dilakukan di provinsi Maluku oleh yang menamakan dirinya Republik Maluku Selatan (RMS) pimpinan Dr. Somoukil tahun 1960-an, juga gerakan teror yang dilakukan oleh Organisasi Papua Merdeka (OPM) di wilayah Irian dimulai sejak tahun 1960, OPM ini bertujuan mendirikan negara Papua yang terbebas dari NKRI terakhir dipimpin oleh Kelly Kwalik.

Demikianlah seterusnya terhadap gerakan-gerakan bersenjata yang menimbulkan korban jiwa, oleh pemerintah Indonesia disebutnya sebagai teroris. Seperti gerakan PGRS/Paraku (Pasukan Gerilya Revolusioner Serawak/Pasukan Rakyat Kalimantan Utara) yang melakukan penyerangan pada pangkalan udara Singkawang pada 16 Juli 1957. Juga tahun 1981 di Lampung Kasus Teror Warman (KTW) yang merupakan sempalan dari D.I./T.I.I dan yang paling mutakhir adalah teroris Jamaah Islamiyah dengan tokohnya Dr. Azhari dan Nurdin M. Top (Warga Negara Malaysia) serta Dulmatin dan Umar Patek, serta Amrozi, Muklas dan Imam Samudra yang merupakan para aktor intelektual dari kasus Bom Bali tahun 2001.

Fenomena terorisme di Indonesia muncul kembali pasca perang dingin. Aksi teroris yang terjadi di Indonesia sejak perang dingin dimulai dengan terror bom Bali 2001. pemerintah Indonesia di awal reformasi telah melakukan langkah-langkah pencegahan secara yuridis dengan mengeluarkan undangundang anti teroris yaitu Undang-Undang Nomor 15 Tahun 200. Sedangkan secara fisik yaitu dengan meningkatkan pencegahan dengan membentuk satu kesatuan keamanan yaitu Densus 88 .

Ketentuan mengenai tindak pidana terorisme di Indonesia diatur dalam Undang-Undang Nomor 15 Tahun 2003. Falsafah yang terkandung dalam

\footnotetext{
${ }^{3}$ Di Indonesia Ekstrimis mengandung pengertian suatu tindakan atau sikap yang keras/radikal bertentangan dan berlawanan derngan kebijakan politik pemerintah.
} 
Undang-Undang Pemberantasan Tindak Pidana Terorisme bahwa Terorisme adalah merupakan musuh umat manusia, kejahatan terhadap peradaban, merupakan Transnational Organized Crimes. Tujuan dari terbentuknya Undang-Undang Pemberantasan Tindak Pidana Terorisme adalah perlindungan pada masyarakat, sedangkan paradigma pembentukan Undang-Undang Pemberantasan Tindak Pidana Terorisme yang merupakan paradigma tritunggal, yaitu melindungi wilayah Negara Kesatuan Republik Indonesia, Hak Asasi Manusia, dan Perlindungan Hak Asasi Tersangka. Juga meliputi semua warga negara Indonesia yang berada di luar wilayah negara Indonesia, termasuk fasilitas Republik Indonesia di luar negeri. Undang-undang Tindak pidana terorisme ini berlaku juga di atas tempat yang berbendera negara Republik Indonesia atau pesawat udara yang terdaftar ke dalam UndangUndang Negara Republik Indonesia pada saat kejahatan itu dilakukan atau oleh setiap orang yang tidak memiliki kewarganegaraan dan bertempat tinggal di wilayah negara Republik Indonesia.

Dalam Pasal 6 dan Pasal 7 UU No. 15 Tahun 2003 dirumuskan mengenai definisi dari tindak pidana terorisme.

Pasal 6

Setiap orang yang dengan sengaja menggunakan kekerasan atau ancaman kekerasan menimbulkan suasana teror atau rasa takut terhadap orang secara meluas atau menimbulkan korban yang bersifat massal, dengan cara merampas kemerdekaan atau hilangnya nyawa dan harta benda orang lain, atau mengakibatkan kerusakan atau kehancuran terhadap objek-objek vital strategis atau lingkungan hidup atau fasilitas publik atau fasilitas internasional, dipidana dengan pidana mati atau penjara seumur hidup atau pidana penjara paling singkat 4 (empat) tahun dan paling lama 20 (dua puluh) tahun.

Pasal 7

Setiap orang yang dengan sengaja menggunakan kekerasan atau ancaman kekerasan bermaksud untuk menimbulkan suasana teror atau rasa takut terhadap orang secara meluas atau menimbulkan korban yang bersifat massal dengan cara merampas kemerdekaan atau hilangnya nyawa atau harta benda orang lain, atau untuk menimbulkan kerusakan atau kehancuran terhadap objek-objek vital yang strategis, atau lingkungan hidup, atau fasilitas publik, atau fasilitas internasional, dipidana dengan pidana penjara paling lama seumur hidup.

Pasal 6 merupakan delik meteril sehingga harus dibuktikan akibat dari perbuatan berupa munculnya suasana teror atau rasa takut yang meluas atau menimbulkan korban yang bersifat massal, sedangkan Pasal 7 merupakan delik formil sehingga yang harus dibuktikan adalah adanya maksud untuk 
menimbulkan suasana teror atau rasa takut yang meluas atau menimbulkan korban yang bersifat massal, walaupun ancaman kekerasan atau kekerasannya belum dilakukan.

Rumusan Pasal 6 dan Pasal 7, masing-masing bisa ditafsirkan, yaitu meliputi dua macam tindak pidana bila dilihat dari akibatnya, yaitu:

1. Menggunakan kekerasan atau ancaman kekerasan yang menimbulkan suasana teror atau rasa takut terhadap orang secara meluas atau menimbulkan korban yang bersifat massal, dengan cara merampas kemerdekaan atau hilangnya nyawa dan harta benda orang lain.

2. Rumusan tindak pidana ini menitikberatkan pada munculnya akibat, yaitu suasana teror atau rasa takut terhadap orang secara meluas atau menimbulkan korban yang bersifat massal dan cara yang digunakan yaitu: merampas kemerdekaan atau hilangnya nyawa dan harta benda orang lain (dalam Pasal 7 harus dibuktikan maksud untuk mencapai akibat tersebut). Yang perlu diperjelas dari rumusan ini adalah apa yang dimaksud dengan suasana teror? Kalau yang dimaksud adalah ketakutan atau korban secara massal; seharusnya "suasana teror" tidak dimasukkan lagi karena bisa ditafsirkan sepihak.

3. Menggunakan kekerasan atau ancaman kekerasan yang mengakibatkan kerusakan atau kehancuran terhadap objek-objek vital yang strategis atau lingkungan hidup atau fasilitas publik atau fasilitas internasional.

4. Rumusan ini dapat ditafsirkan menjadi tindakan sendiri karena samasama merupakan akibat yang ditimbulkan seperti ketakutan dan korban massal sehingga kedudukannya sejajar dalam struktur kalimat, dan tidak bisa disejajarkan dengan unsur "dengan cara". Hal ini sangat berbahaya karena mengandung ketidakjelasan tentang perbuatan kekerasan apa sebagai caranya, serta apa yang dimaksud dengan objek vital strategis, lingkungan hidup, fasilitas publik, dan fasilitas internasional.

Dalam ketentuan pasal ini dianggap sebagai tindak pidana terorisme perbuatan yang berkaitan dengan keamanan dan keselamatan penerbangan, tercantum dalam Pasal 8 sampai dengan Pasal 19.

Pasal 6 dan 7 telah diberalakukan secara efektif sejak tahun 2003 yaitu sejak diberlakukannya Undang-undang No. 15 Tahun 2003. Hal ini merupakan langkah strategis yang merupakan usaha pencegahan dari Pemerintah Indonesia untuk menanggulangi terorisme dari aspek hukum.

Akan tetapi setelah diberlakukannya Undang-Undang Nomor 15 Tahun 2003 kasus-kasus terorisme masih terus berjalan dengan intensitas yang makin tinggi.

Kejadian terorisme tetap saja terjadi dimulai dengan peristiwa pemboman Hotel Marriot Jakarta tahun 2003, kemudian pembomban kedutaan Australia disusul dengan pemburuan terhadap Dr. Azhari dan Nurdin M. Top. Pada dekade terakhir intensitas kegiatannya makin meninggi, di berbagai tempat di daerah (Cirebon, Majalengka, Bekasi dan Poso) maupun di pusat pemerintahan Jakarta. 
Dengan demikian masalah terorisme menjadi penting dan menarik untuk dikaji. Untuk itu perlu kajian lebih lanjut. Kegiatan terorisme di Indonesia mempunyai berbagai segi yang menarik untuk dikaji. Segi politik, agama, sosial budaya dan hukum. Dalam tulisan ini akan dikaji masalah terorisme dipandang dari sudut hukum serta bagaimana cara penanggulangannya.

Tulisan ini disusun dengan metode penulisan yuridis normatif yaitu dengan mempelajari peraturan perundang-undangan baik yang ada dalam undang-undang itu sendiri maupun yang ada dalam literatur/buku ilmu pengetahuan hukum, khususnya perundang-undangan yang berkaitan dengan terorisme. Kemudian hasilnya yang berupa aspek yuridis, historis, maupun sosiologis dituangkan dalam bentuk deskriptif analitis.

\section{Pengertian dan Ciri-ciri Terorisme}

Kata "teroris" (pelaku) dan terorisme (aksi) berasal dari kata latin "terrere" yang artinya kurang lebih berarti membuat gemetar atau menggetarkan. ${ }^{4}$ Kata "Teror" juga bisa menimbulkan kengerian. Tentu saja, kengerian di hati dan pikiran korbannya. Akan tetapi, hingga kini tidak ada definisi terorisme yang bisa diterima secara universal. Pada dasarnya, istilah "terorisme" merupakan sebuah konsep yang memiliki konotasi yang sangat sensitive karena terorisme menyebabkan terjadinya pembunuhan dan penyengsaraan terhadap orang-orang yang tidak berdosa.

Pengertian terorisme masih menjadi perdebatan meskipun sudah ada ahli yang merumuskan, dan dirumuskan dalam peraturan perundang-undangan. Meskipun begitu, bukan berarti terorisme tidak termasuk kejahatan.

Ketidak seragaman pengertian hukum internasional mengenai terorisme tidak serta-merta berarti meniadakan definisi hukum tentang terorisme itu. Menurut hukum nasional masing-masing negara-negara, di samping bukan berarti meniadakan sifat jahat perbuatan itu dan dengan demikian lantas bisa diartikan bahwa pelaku terorisme bebas dari tuntutan hukum. Nullum crimen sine poena, begitu bunyi sebuah asas hukum tua, yang bermakna, bahwa tiada kejahatan yang boleh dibiarkan berlalu begitu saja tanpa hukuman.

Amerika Serikat misalnya menganggap Irak sebagai teroris karena dianggap memiliki senjata pemusnah masal, namun di sisi lain justru banyak negara yang mengangap Amerika-lah teroris sejati dan layak diposisikan sebagai kekuatan adidaya dalam kasus "terorisme negara" (state terrorism) karena telah melakukan invasi ke negara yang berdaulat tanpa persetujuan dewan keamanan PBB. Invasi Amerika ke Irak, oleh para pengamat politik, dianggap sebagai tindakan yang tidak sah (illegal) karena tidak mendapat persetujuan PBB sebagai lembaga yang memiliki otoritas tertinggi dunia, tidak bermoral (Immoral) karena tidak menghormati hak asasi manusia (HAM), dan gila $(\mathrm{mad})$ karena invasi dilakukan dengan membabi buta sehingga banyak

4 Abdul Wahid, dan kawan-kawan, "Kejahatan Terorisme", (Malang: Refika Aditama, 2003), hal. 22. 
rakyat sipil yang menjadi korban. Perumusan mengenai pengertian terorisme menimbulkan persoalan multi-interpretasi.

Sedangkan pengertian dan batasan terorisme secara yuridis menurut hukum Indonesia yaitu sebagaimana telah disinggung terdahulu dalam tulisan ini, yaitu sebagaimana dirumuskan dalam Pasal 6 dan 7 Undang-undang No. 15 Tahun 2003, yaitu:

Pasal 6

Setiap orang yang dengan sengaja menggunakan kekerasan atau ancaman kekerasan menimbulkan suasana teror atau rasa takut terhadap orang secara meluas atau menimbulkan korban yang bersifat massal, dengan cara merampas kemerdekaan atau hilangnya nyawa dan harta benda orang lain, atau mengakibatkan kerusakan atau kehancuran terhadap objek-objek vital strategis atau lingkungan hidup atau fasilitas publik atau fasilitas internasional, dipidana dengan pidana mati atau penjara seumur hidup atau pidana penjara paling singkat 4 (empat) tahun dan paling lama 20 (dua puluh) tahun.

Pasal 7

Setiap orang yang dengan sengaja menggunakan kekerasan atau ancaman kekerasan bermaksud untuk menimbulkan suasana teror atau rasa takut terhadap orang secara meluas atau menimbulkan korban yang bersifat massal dengan cara merampas kemerdekaan atau hilangnya nyawa atau harta benda orang lain, atau untuk menimbulkan kerusakan atau kehancuran terhadap objek-objek vital yang strategis, atau lingkungan hidup, atau fasilitas publik, atau fasilitas internasional, dipidana dengan pidana penjara paling lama seumur hidup.

Sedangkan ciri terorisme ditinjau dari dua macam pengelompokan yang terdiri dari:

Pertama, karakteristik organisasi yang meliputi : organisasi, rekrutmen, pendanaan dan hubungan internasional. Karakteristik operasi yang meliputi : perencanaan, waktu, taktik dan kolusi.

Kedua, karakteristik perilaku yang meliputi : motivasi, dedikasi, disiplin, keinginan membunuh dan keinginan menyerah hidup-hidup. Karakteristik di bidang teknologi, persenjataan, perlengkapan dan transportasi. Motif Terorisme, teroris terinspirasi oleh motif yang berbeda. Motif terorisme dapat diklasifikasikan menjadi tiga kategori : rasional, psikologi dan budaya.

Teroris sebagai organisasi dalam konteks pandangan barat bisa diambil contoh, misalnya organisasi seperti PLO (People Liberty Organization), HAMAS, Gerakan Intifada (di Timur Tengah khususnya Palestina), IRA (Irlandia Republic Army) atau Komando Jihad dan KNN KW 9 di Indonesia, merupakan terorisme dalam konteks organisasi. Sedangkan teroris dalam arti 
individual dan merupakan kegiatan kriminal murni adalah merupakan terorisme bukan dalam bentuk organisasi.

\section{Bentuk-bentuk Terorisme}

Ada beberapa bentuk terorisme yang dikenal yaitu antara lain teror kriminal, dan teror politik. Teror kriminal biasanya hanya untuk kepentingan pribadi atau meperkaya diri sendiri. Teroris kriminal bisa menggunakan cara pemerasan dan intimidasi. Mereka menggunakan kata-kata yang dapat menimbulkan ketakutan atau teror psikis. Lain halnya dengan teror politik bahwasannya teror politik tidak memilih-milih korban. Teroris politik selalu siap melakukan pembunuhan terhadap orang-orang sipil: laki-laki, perempuan, dewasa, atau anak-anak dengan tanpa mempertimbangkan penilaian politik atau moral. Terorisme politis memiliki karakteristik : merupakan intimidasi koersif, memakai pembunuhan dan destruksi secara sistematis sebagai sarana untuk tujuan tertentu; korban bukan tujuan, melainkan sarana untuk menciptakan perang urat syaraf, yakni "bunuh satu orang untuk menakuti seribu orang"; target aksi teror dipilih, bekerja secara rahasia, namun tujuannya adalah publisitas; pesan aksi itu cukup jelas, meski pelaku tidak selalu menyatakan diri secara personal; para pelaku kebanyakan dimotivasi oleh idealisme yang cukup keras, misalnya "berjuang demi agama dan kemanusiaan".

Dengan demikian, teror adalah suatu kesatuan aksi tak langsung dan terarah untuk mencapai hasil politik tertentu melalui dampak yang ditimbulkannya. Dari kacamata strategi politik, teror merupakan aksi sekunder dan bukan yang utama. Artinya, teror jarang sekali merupakan aksi atau tujuan utamanya atau akai yang independent. ${ }^{5}$

Kalau dilihat dari sejarahnya maka, tipologi terorisme terdiri dari beberapa bentuk yaitu: Bentuk pertama, terdiri atas pembunuhan politik terhadap pejabat pemerintah itu terjadi sebelum Perang Dunia II. Bentuk yang Kedua, terorisme dimulai di Al-jazair di tahun lima puluhan, yang mempopulerkan "serangan yang bersifat acak" terhadap masyarakat sipil yang tidak berdosa. Hal ini untuk melawan apa yang mereka sebut sebagai "terorisme negara". Menurut mereka pembunuhan dengan tujuan untuk mendapatkan keadilan bukanlah soal yang harus dirisaukan, bahkan sasaran mereka adalah yang tidak berdosa.

Bentuk ketiga terorisme muncul pada tahun enam puluhan dan terkenal dengan istilah "terorisme media", berupa serangan acak atau random terhadap siapa saja dengan tujuan publisitas. Dalam masyarakat yang sebagian besar buta huruf dan apatis, seruan atau perjuangan melalui huruf-huruf tertulis dampaknya sangat kecil, sehingga lebih efektif menerapkan "filsafat bom", yakni bersifat eksplosif dan sangat sulit untuk mengabaikannya.

\footnotetext{
${ }^{5}$ Forum Keadilan, 3 November 2008, hal. 18.
} 
Jadi dengan demikian bahwa ada dua bentuk terorisme, yang pertama apa yang disebut dengan teror kriminal, dan teror politik. Kalau mengenai teror kriminal biasanya hanya untuk kepentingan pribadi atau memperkaya diri sendiri. Teroris kriminal bisa menggunakan cara pemerasan dan intimidasi. Mereka menggunakan kata-kata yang dapat menimbulkan ketakutan atau teror psikis. Lain halnya dengan teror politik bahwasannya teror politik tidak memilih-milih korban. Teroris politik selalu siap melakukan pembunuhan terhadap orang-orang sipil: laki-laki, perempuan, dewasa atau anak-anak tanpa mempertimbangkan penilaian politik atau moral, teror politik adalah suatu fenomena sosial yang penting. Yang disepakati oleh berbagai negara bahwa semua kegiatan terorisme mempunyai motivasi politik. Dan kegiatan terorisme merupakan suatu kejahatan kriminal.

Munculnya istilah "terorisme" yang menjadi wacana paling popular dibincangkan oleh khalayak dunia dan mempunyai implikasi besar bagi tatanan politik. Wacana ini menyeruak sejak hancurnya gedung pencakar langit, World Trade Center (WTC) dan Pentagon, New York, yang diserang oleh sebuah kelompok pembajak pesawat yang sampai saat ini masih belum diketahui atau masih misterius. Pelaku yang sering disebut-sebut sebagai aktor di balik aksi penyerangan tersebut adalah jaringan internasional Al-Qaedah. Inilah yang kemudian menjadi tanda tanya besar, apa sebenarnya terorisme itu ? Dan siapa yang melakukannya? Serta mengapa mereka jadi teroris?

Terorisme merupakan suatu paham yang berbeda dengan kebanyakan paham di dunia, baik dulu maupun yang mutakhir. Terorisme selalu identik dengan teror, kekerasan, ekstrimitas dan intimidasi serta sebutan bagi para pelakunya biasa disebut dengan teroris. Terorisme acapkali menjatuhkan korban kemanusiaan dalam jumlah yang tidak sedikit. Ada sasaran yang terorganisir secara intelektual, modus operadinya terencana, termasuk misalnya menjadikan sandera sebagai "tameng hidup" untuk memperlancar dan menyukseskan aksi kekerasannya. Nyawa manusia akhirnya tidak menjadi subjek yang dimartabatkan.

\section{Terorisme Menurut Pandangan Agama Islam}

Dari sudut pandang Islam, Azyumardi Azra, Rektor Universitas Islam Negeri Jakarta mengatakan bahwa terorisme sebagai kekerasan politik sepenuhnya bertentangan dengan etos kemanusiaan agama Islam. Islam mengajarkan etos kemanusiaan yang sangat menekankan kemanusiaan universal. "Islam menganjurkan umatnya untuk berjuang mewujudkan perdamaian, keadilan, dan kehormatan, akan tetapi, perjuangan itu haruslah tidak dilakukan dengan cara-cara kekerasan atau terorisme. Setiap perjuangan untuk keadilan harus dimulai dengan premis bahwa keadilan adalah konsep universal yang harus diperjuangkan dan dibela setiap manusia. Islam memang menganjurkan dan memberi justifikasi kepada muslim untuk berjuang, berperang (harb), dan menggunakan kekerasan (qital) terhadap para penindas, musuh-musuh Islam, dan pihak luar yang menunjukkan sikap bermusuhan atau 
tidak mau hidup berdampingan secara damai dengan Islam dan kaum muslimin. ${ }^{6}$

Islam sebagai agama yang Rahmatan lil alamin, jelas menolak dan melarang penggunaan kekerasan demi untuk mencapai tujuan-tujuan (alghoyat), termasuk tujuan yang baik sekalipun. Sebuah kaidah Ushul dalam Islam menegaskan al-ghayah la tubarrir al wasilah (tujuan tidak bisa menghalalkan segala cara). Islam menegaskan bahwa pembasmian suatu jenis kemungkinan tidak boleh dilakukan dengan kemungkinan pula. Tidak ada alasan etik dan moral sedikitpunyg bisa membenarkan suatu tindakan kekerasan, terlebih teror. Dengan demikian kalau ada tindakan-tindakan teror yang dilakukan oleh kelompok Islam tertentu, maka suatu pasti alasannya bukan karena ajaran etik moral Islam, melainkan agenda lain yang tersembunyi di balik tempurung tindakan tersebut. ${ }^{7}$

Akan halnya gerakan yang telah dilakukan oleh gerakan Islam NII/DI TII "palsu" adalah hal yang lain yang perlu bahasan tersendiri.

\section{Perundang-undangan Terorisme Indonesia}

Sebelum berlaku Undang-undang No. 15 Tahun 2003 terhadap gerakan dan kegiatan teroris ini, Indonesia mempunyai perangkat perundang-undangan sebagai alat pencegahnya dan penindakannya. Sejak tahun 1963 berlaku undang-undang no. 11/PNPS/1964 tentang Pemberantasan Kegiatan Subversi. Menurut undang-undang ini, perbuatan teror bisa dijerat dengan undangundang Subversi. Adapun rumusan yang dapat menjerat dari tindakan terorisme tersebut diatur dalam Pasal 1 (1):

Barang siapa melakukan perbuatan, dengan maksud atau nyatanyata dengan maksud atau yang diktehauinya atau patut diketahuinya dapat: menggulingkan, merusak atau merongrong kekuasaan negara atau kewibawaan pemerintah yang sah atau mengacaukan bagi industri, produksi distribusi, perdagangan, koperasi atau pengangkutan.

Pasal XIX ayat (1) 5: Barang siapa melakukan sabotase.

Undang-undang ini pada masa orde lama dan orde baru selalu digunakan untuk menjerat terorisme yang dapat dikategorikan sebagai kegiatan subversi, yang nota bene pelaku-pelakunya mayoritas adalah orang-orang dari organisasi Islam, baik dalam skala perorangan maupun kelompok-oraganisasi jamaah-. Sejak awal diundangkannya undang-undang subversi sudah mendapat tentangan yang luas khusunya dari organisasi-organisasi islam, juga para aktifis

${ }^{6}$ Kompas, 2 November 2001, hal. 10.

${ }^{7}$ Duta Masyarakat, 22 September 2002, hal. 6. 
Hak Azasi Manusia serta para pengacara/advokat. Karena rumusan pasal-pasal pidananya bersifat karet-elastis-. Hal ini mengandung pengertian rumusan pasal-pasal pidananya dapat menjerat perbuatan apa saja dan siapa saja, sehingga sepanjang masa berlakunya undang-undang subversi, di era orde lama dan orde baru dituntut untuk dicabut dan dinyatakan tidak berlaku. Barulah pada era reformasi, di jaman presiden Megawati Soekarnoputri, undangundang tentang subversi ini dicabut dan dinyatakan tidak berlaku lagi. ${ }^{8}$

Sejak itu terhadap tindakan terorisme tidak ada payung hukum, tidak ada hukum yang khusus yang mengaturnya, walaupun terorisme secara terbatas bisa dijerat dengan pasal-pasal dalam Kitab Undang-undang Hukum Pidana (KUHP). Akan tetapi di dalam KUHP sanksi pidananya begitu rendah dan tidak mempunyai daya tangkal yang kuat.

Barulah pada tahun 2003, dikeluarkan undang-undang yang mengatur tentang terorisme, yaitu undang-undang no. 15 tahun 2003 tentang Peraturan Pemerintah Pengganti Undang-undang. Rumusan pidana terorismenya diantaranya ada dalam:

Pasal 6

Setiap orang yang dengan sengaja menggunakan kekerasan atau ancaman kekerasan menimbulkan suasana teror atau rasa takut terhadap orang secara meluas atau menimbulkan korban yang bersifat massal, dengan cara merampas kemerdekaan atau hilangnya nyawa dan harta benda orang lain, atau mengakibatkan kerusakan atau kehancuran terhadap obyek-obyek vital yang strategis atau lingkungan hidup atau fasilitas publik atau fasilitas internasional, dipidana dengan pidana mati atau penjara seumur hidup atau pidana paling singkat 4 (empat) tahun dan paling lama 20 (dua puluh) tahun.

Pasal 7

Setiap orang yang dengan sengaja menggunakan kekerasan atau ancaman kekerasan bermaksud untuk menimbulkan suasana teror atau rasa takut terhadap orang secara meluas atau menimbulkan korban yang bersifat massal dengan cara merampas kemerdekaan atau hilangnya nyawa atau harta benda orang lain, atau untuk menimbulkan kerusakan atau kehancuran terhadap obyek-obyek vital yang strategis, atau lingkungan hidup, atau fasilitas publik, atau fasilitas internasional, dipidana dengan pidana penjara paling lama seumur hidup.

\footnotetext{
${ }^{8}$ Mien Rukmini, "Perlindungan Ham, Melalui Asas Praduga Tak Bersalah Dan Asas Persamaan Kedudukan Dalam Hukum Pada Sistem Peradilan Pidana Indonesia”, (Bandung: Alumni, 2003), hal. 32.
} 
Selain rumusan pasal 6 di atas, masih ada pasal lain yang merumuskan tentang pidana terorisme, cakupannya lebih luas dibandingkan dengan rumusan pidana seperti dalam undang-undang subversi tapi lebih pasti, tidak bersifat karet. Adapun ancaman pidana paling tinggi sama dengan ancaman pidana seperti dalam tindak pidana subversi, yaitu maksimal hukuman mati.

Dalam undang-undang no. 15 tahun 2003 di jelaskan bahwa terorisme merupakan kejahatan lintas negara, terorganisasi, dan mempunyai jaringan luas sehingga mengancam perdamaian dan keamanan nasional maupun internasional.

Terorisme merupakan kejahatan terhadap kemanausiaan dan peradaban serta merupakan salah satu ancaman serius terhadap kedaulatan setiap Negara karena terorisme sudah merupakan kejahatan yang bersifat internasional yang menimbulkan bahaya terhadap keamanan, perdamaian dunia serta merugikan kesejahateraan masyarakat sehingga perlu dilakukan pemberantasan secara berencana dan berkesinambungan.

Komitmen masyarakat internasional dalam mencegah dan memberantas terorisme sudah diwujudkan dalam berbagai konvensi internasional yang menegaskan bahwa terorisme merupakan kejahatan yang mengancam perdamaian dan keamanan umat manusia sehingga seluruh anggota Perserikatan Bangsa-Bangsa termasuk Indonesia wajib mendukung dan melaksanakan resolusi Dewan Keamanan Perserikatan Bangsa-Bangsa yang mengutuk dan menyerukan seluruh anggota Perserikatan Bangsa-Bangsa untuk mencegah dan memberantas terorisme melalui pembentukan peraturan perundang-undangan nasional negaranya.

Pemberantasan tindak pidana terorisme di Indonesia merupakan kebijakan dan langkah antisipatif yang bersifat proaktif yang dilandaskan kepada kehati-hatian dan bersifat jangka panjang karena:

Pertama, masyarakat Indonesia adalah masyarakat multi-etnik dengan beragam dan mendiami ratusan ribu pulau-pulau yang tersebar di seluruh wilayah nusantara serta ada yang letaknya berbatasan dengan Negara lain.

Kedua, dengan karakteristik masyarakat Indonesia tersebut seluruh komponen bangsa Indonesia berkewajiban memelihara dan meningkatkan kewaspadaan menghadapi segala bentuk kegiatan yang merupakan tidak pidana terorisme yang bersifat internasional.

Ketiga, konflik-konflik yang terjadi sangat merugikan kehidupan berbangsa dan bernegara serta merupakan kemunduran peradaban dan dapat dijadikan tempat yang subur berkembangnya tindak pidana terorisme yang bersifat internasional baik yang dilakukan oleh warga Negara Indonesia maupun yang dilakukan oleh orang asing.

Terorisme yang bersifat internasional merupakan kejahatan yang terorganisasi, sehingga pemerintah dan bangsa Indonesia wajib meningkatkan kewaspadaan dan bekerja sama memelihara keutuhan Negara Kesatuan Republik Indonesia.

Pemberantasan tindak pidana terorisme di Indonesia tidak semata-mata merupakan masalah hukum dan penegakan hukum melainkan juga merupakan masalah social, budaya, ekonomi yang berkaitan erat dengan masalah 
ketahanan bangsa sehingga kebijakan dan langkah pencegahan dan pemberantasannya pun ditujukan untuk memelihara keseimbanan dalam kewajiban melindugi kedaulantan Negara, hak asasi korban dan saksi, serta hak asasi tersangka/terdakwa.

Pemberantasan tidak pidana terorisme dengan ketiga tujuan di atas menunjukkan bahwa bangsa Indonesia adalah bangsa yang menjunjung tinggi peradaban umat manusia dan memiliki cita perdamaian dan mendambakan kesejahteraan serta memiliki komitmen yang kuat untuk tetap menjaga keutuhan wilayah Negara Kesatuan Repubik Indonesia yang berdaulat di tengah-tengah gelombang pasang surut perdamaian dan keamanan dunia.

Pemerintah Indonesia sejalan dengan amanat sebagaimana ditentukan dalam Pembukaan Undang-Undang Dasar Negara Republik Indonesia Tahun 1945 yakni melindungi segenap bangsa Indonesia dan seluruh tumpah darah Indonesia, memajukan kesejahteraan umum, mencerdaskan kehidupan bangsa dan ikut serta dalam memelihara ketertiban dunia yang berdasarkan kemerdekaan dan perdamaian abadi dan keadilan social, berkewajiban untuk melindungi warganya dari setiap ancaman kejahatan baik bersifat nasional, transnasional, maupun bersifat internasional. Pemerintah juga berkewajiban untuk mempertahankan kedaulatan serta memelihara keutuhan dan integritas nasional dari setiap bentuk ancaman baik yang dating dari luar maupun dari dalam. Untuk itu, maka mutlak diperlukan penegakan hukum dan ketertiban secara konsisten dan berkesinambungan.

Untuk menciptakan suasana tertib dan aman, maka dengan mengacu pada konvensi internasional dan peraturan perundang-undangan yang berkaitan dengan terorisme, serta untuk memberikan landasan hukum yang kuat dan kepastian hukum dalam mengatasi masalah yang mendesak dalam pemberantasan tindak pidana terosirisme, Presiden Republik Indonesia telah menetapkan Peraturan Pemerintah Pengganti Undang-Undang Nomor 1 Tahun 2002 tentang Pemberantasan Tindak Pidana Terorisme, ditetapkan menjadi undang-undang no. 15 tahun 2003.

Kalau kita perhatikan uraian di atas, maka permasalahan terorisme di Indonesia khususnya, buka hanya persoalan hukum semata-mata namun juga mencakup persoalan prinsip dan idealisme serta aqidah/ideologi. Di samping itu terorisme bukan hanya gerakan lokal akan tetapi sudah merupakan gerakan internasional yang menyangkut persoalan lintas negara dan antar bangsa serta persoalan yang sangat sensitif yang menyangkut keyakinan pelaksanaan suatu syariat agama, kelompok teroris pelaku bom bali 1 dan 2, menyangkal disebut teroris. Tapi menyebut dirinya sebagai mujahid-pejuang penegak asma Allah-. Oleh karena itu dalam menykapinyapun kita harus memandangnya dari beberapa segi, antara lain terorisme sebagai suatu ideologi dan terorisme sebagai suatu aksi sindikat organisasi (Jamaah).

\section{Penanggulangan Terorisme di Indonesia}

Di atas diuraikian bagaimana, usaha-usaha pemerintah Indonesia penguasa Indonesia- melalui jalur hukum dalam usaha memberantas tindak 
pidana terorisme. Sejak tahun 1960 hal ini telah dilaksanakan mulai dari diundangkannya Undang-Undang No. 11/PNPS/1963 tentang pemberantasan tindak pidana subversi, kemudian undang-undang subversi dicabut pasca reformasi karena dinilai terlalu bersifat elastis serta dinilai melanggar Hak Asasi Manusia. Tahun 2003 diundangkan undang-undang no. 15 tahun 2003 tentang pemberantasan tindak pidana terorisme.

Berdasarkan undang-undang subversi telah banyak kaum subversif/ teroris oleh pemerintah orde baru Indonesia ditindak. Beberapa contoh yang menonjol antara lain:

1. Kasus komando Jihad tahun 1974-1978 gerakan ini dinamakan gerakan teroris yang merupakan kelanjutan dari DI/TII pimpinan S.M. Kartosuwiryo yang bertujuan mendirikan daulah islamiah yang berbasis di Indonesia. Komando jihad merupakan neo DI/TII di pimpin oleh mantan petinggi DI/TII baik petinggi militer maupun petinggi sipil antara lain H. Adah Djaelani, T.K. H. Daud Beureuh, H. Ismail Pranoto (Hispran). Tiga tokoh ini merupakan mantan petinggi DI/TII. Ketiga tokoh ini pada saat amnesti umum diberikan oleh presiden Soekarno telah menyatakan sumpah setia pada pemerintah RI. Gerakan komando jihad ternyata bukan merupakan gerakan mujahid islam yang sebenarnya. Gerakan ini tokoh-tokohnya diadili pada tahun 1980-an berdasarkan Undang-undang Subversi.

2. Kasus subversi yang melibatkan Imron dan Salman Hafidz pada tahun 1980 yang melakukan pembajakan pesawat Garuda Airways di Lapangan Terbang Don Muang, Thailand. Pembajakan ini berhasil digagalkan oleh pasukan Kopasus pimpinan Beni Murdani, para pembajak dilumpuhkan dan dibunuh. Pimpinannya yaitu Imron diadili dan dihukum mati pada tahun 1980. Gerakan teroris inipun ditenggarai bukan gerakan pejuang islam yang sesungguhnya.

3. Peristiwa Tanjung Priok tahun 1984 yang melibatkan Mayjend H.R. Darsono Sekjen Asean, mantan Pangdam Siliwangi.peristiwa inipun ditindak berdasarkan Undang-undang Subversi, H.R. Darsono diadili dan dipidana.

Sedangkan berdasarkan undang-undang no. 15 tahun 2003 pemerintah orde reformasi telah melakukan refresif terhadap kegiatan terorisme. Adapun kasus yang menonjol antara lain sebagaimana disinggung pada awal tulisan ini. Teroris jamaah Islamiyah dengan tokohnya Dr. Azhari dan Nurdin M. Top serta Dulmatin dan Umar Patek, serta Amrozi, Muklas dan Imam Samudra yang merupakan para aktor intelektual dari kasus Bom Bali tahun 2001. Kasus teroris inipun telah ditumpas oleh pemerintah RI. Dimana semua tokoh intelektualnya telah terbunuh baik melalui operasi militer maupun melalui jalur peradilan.

Walaupun kegiatan subversi dan terorisme telah ditindak namun demikian kenyataannya kegiatan terorisme masih saja terjadi hingga saat ini di Indonesia. 
Adapun peran aparat penegak hukum di dalam pencegahan dan penindakan terhadap kegiatan terorisme menurut hukum positif di Indonesia, secara regulasi diatur dalam Undang-Undang No. 8 Tahun 1981 tentang Kitab Undang-undang Acara Hukum Pidana (aturan umum), serta Undang-Undang No. 15 Tahun 2003 tentang Pemberantasan Tindak Pidana Terorisme (aturan khusus).

Menurut KUHAP yang mengatur tentang tata cara penanganan perkara pidana atau yang disebut sebagai proses peradilan dimulai dari penyelidikan sampai eksekusi. Yang melakukan penyelidikan dan penyidikan adalah pihak Kepolisian, sedangkan yang melakukan penuntutan dan eksekusi adalah Jaksa Penuntut Umum. Adapun Hakim bersama-sama dengan Jaksa Penuntut Umum serta Advokat/Penasehat Hukum adalah pihak yang melaksanakan proses persidangan di pengadilan, baik Pengadilan Tingkat I, Pengadilan Banding, Pengadilan Kasasi maupun Pengadilan Peninjauan Kembali.

Pihak Polisilah selaku penyidik yang mempunyai kewenangan penyidikan tindak pidana terorisme. Dalam melakukan penyidikannya Polisi bisa melakukan upaya paksa berupa pemanggilan orang (untuk dimintakan keterangan), penangkapan, penahanan, penggeledahan, pensitaan dan pemeriksaan identitas.

Sedangkan Jaksa Penuntut Umum melakukan penuntutan di samping melakukan eksekusi serta bersama-sama dengan Hakim dan Advokat bersidang di Pengadilan.

Adapun peran objektif yang telah dilakukan oleh aparat penegak hukum di atas di dalam melakukan kegiatan penindakan terorisme di Indonesia, adalah seperti yang telah dilakukan selama ini yang paling mutakhir ialah penanganan perkara terorisme yang dilakukan oleh Amrozi dan kawan-kawan dalam perkara Bom Bali. Dimana para pelakunya telah dieksekusi.

Perangkat hukum yang telah berlaku sejak tahun 2003 untuk mengatasi dan memberantas terorisme tersebut dalam implementasinya terutama yang diterapkan oleh aparat penegak hukum khususnya pihak Kepolisian belum optimal dalam menanggulangi tindak pidana terorisme, hal ini dibuktikan dengan makin meningkatnya frekuensi dan akselerasi kegiatan terorisme di Indonesia.

Ketidakoptimalan penegak hukum di dalam menanggulangi dan memberantas terorisme disebabkan oleh beberapa hal yaitu antara lain faktor psikologis yang melatarbelakangi gerakan teroris di Indonesia yang mempunyai ideologi Islam, faktor teknis dimana gerakan terorisme bukan hanya gerakan lokal tapi sudah menjadi gerakan internasional yang mengglobal dengan cara-cara aksi-aksi terorisme yang canggih dengan menggunakan teknologi modern yang dilakukan dengan jaringan internasional yang rapih, hal ini tidak tercover oleh aparat keamanan dan penegak hukum di Indonesia. 


\section{Penutup}

\section{Kesimpulan}

Tujuan hukum yang hakiki adalah untuk mencapai keadilan di masyarakat. Selain juga untuk tercapainya kepastian hukum. Namun untuk tercapainya keadilan di masyarakat maka di masyarakat itu harus tercipta ketertiban, tanpa ketertiban tidak mungkin adanya keadilan.

Keadaan yang tidak tertib seperti terjadinya aksi teroris yang menimbulkan korban manusia baik tewas maupun luka, serta rusaknya berbagai sarana dan bangunan strategis maupun milik masyarakat, akan menimbulkan rasa tidak aman di masyarakat. Dalam suasana ini keadilan di masyarakat tidak akan tercipta.

Kondisi chaos yang menimbulkan kondisi tidak aman ini terjadi akhir-akhir ini di Indonesia akibat dari aksi-aksi terorisme. Gerakan dan aksi terorisme bukan hanya aktivitas lokal di Indonesia saja, tapi merupakan aktivitas yang mencakup regional bahkan bersifat jaringan internasional. Gerakan dan aktivitas terorisme di Indonesia, baik perorangan maupun organisasi banyak dilatarbelakangi oleh suatu ideologi yaitu ideologi Islam, sehingga dalam penyelesaiannyapun tidak cukup dengan pendekatan yuridis tetapi harus menyertakan pendekatan sosiologis religius.

Kegiatan dan gerakan terorisme di Indonesia, baik terorisme yang dilakukan secara perorangan maupun dilakukan dengan terorganisir dalam bentuk organisasi telah ada peraturan perundang-undangan yang mengaturnya yang bersifat pencegahan dan penindakan, yaitu UndangUndang Nomor 15 Tahun 2003 dalam Pasal 6 dan Pasal 7 dirumuskan definisi dari tindak pidana terorisme:

Pasal 6

Setiap orang yang dengan sengaja menggunakan kekerasan atau ancaman kekerasan menimbulkan suasana teror atau rasa takut terhadap orang secara meluas atau menimbulkan korban yang bersifat massal, dengan cara merampas kemerdekaan atau hilangnya nyawa dan harta benda orang lain, atau mengakibatkan kerusakan atau kehancuran terhadap objek-objek vital strategis atau lingkungan hidup atau fasilitas publik atau fasilitas internasional, dipidana dengan pidana mati atau penjara seumur hidup atau pidana penjara paling singkat 4 (empat) tahun dan paling lama 20 (dua puluh) tahun.

\section{Pasal 7}

Setiap orang yang dengan sengaja menggunakan kekerasan atau ancaman kekerasan bermaksud untuk menimbulkan suasana teror 
atau rasa takut terhadap orang secara meluas atau menimbulkan korban yang bersifat massal dengan cara merampas kemerdekaan atau hilangnya nyawa atau harta benda orang lain, atau untuk menimbulkan kerusakan atau kehancuran terhadap objek-objek vital yang strategis, atau lingkungan hidup, atau fasilitas publik, atau fasilitas internasional, dipidana dengan pidana penjara paling lama seumur hidup.

Peraturan perundang-undangan seperti tercantum di atas belum mampu menanggulangi gerakan terorisme di Indonesia secara tuntas, sehingga perlu reaktualisasi dari paradigma pemberantasan terorisme di Indonesia yaitu dengan lebih mengedepankan aspek psikologis dibandingkan dengan mengedepankan pendekatan keamanan dan yuridis.

\section{Saran}

Masalah terorisme sebagaimana disampaikan di atas harus ada jalan penanggulangannya. Ada beberapa solusi yang bisa dijadikan jalan keluar untuk menanggulangi terorisme.

Bahwa terorisme seperti telah diuraikan di atas bukan hanya persoalan hukum saja tetapi sudah menyangkut persoalan politis, persoalan agama, persoalan keyakinan dan persoalan aqidah/ideologi. Soal aqidah/keyakinan untuk melaksanakan agama merupakan hak yang mendasar bagi semua umat manusia, di Indonesia hal ini dijamin oleh Undang-undang Dasar 1945. ${ }^{9}$ Terhadap persoalan ini karena menyangkut banyak orang, termasuk di Indonesia jumlah umat Islam merupakan umat Islam terbesar di dunia, maka pendekatannya bukan hanya bersifat represif yuridis akan tetapi juga pendekatan psikologis religius, khususnya Pemerinatah Indonesia harus sedikit mengulurkan tangan menampung serta mengakomodir aspirasi umat Islam Indonesia. Pemerintah Indonesia harus mempunyai empati kepada kaum muslimin untuk memberikan ruang dan waktu kepadanya, dalam penjaminan menjalankan syariat islam bagi pemeluk-pemeluknya, sebab kasus-kasus terorisme yang terjadi di Indonesia yang belakangan ini terjadi, seluruhnya melibatkan para aktifis muslim. Namun demikian tetaplah bahwa siapapun dan dari golongan manapun yang melakukan tindakan teror dan menyebarkan terorisme harus ditindak sesuai dengan hukum.

Bahwa terorisme bukan suatu kegiatan yang sifatnya pribadi orang perorangan juga bukan bersifat lokal, tetapi sudah merupakan kegiatan lintas negara atau sudah merupakan gerakan internasional. Oleh sebab itu sisarankan cara penanganannya pun tidak hanya oleh Pemerintah Indonesia saja, tapi harus dilakukan bersama-sama dengan negara lain

${ }^{9}$ Subhi Mahmassani, “Arkan Huquq'l--Insan (Konsep Dasar Hak Asasi ManusiaStudi Perbandingan dalam Syariat Islam dan Perundang-undangan Modern)”, Alih Bahasa: Hasanudin, (Jakarta: Tintamas Indonesia, 1993), hal. 48. 
yang bersifat lintas negara, baik dengan negara tetangga maupun negara lain/antar negara. 


\section{Daftar Pustaka}

Adjie S. Terorisme, Jakarta: Pustaka Sinar Harapan, 2005.

Al-Anshari, Fauzan. Saya Teroris: Sebuah “Pledoi”, Jakarta: Republika, 2002.

Atmasasmita, Romli. Masalah Pengaturan Terorisme dan Perspektif Indonesia, Departemen Kehakiman dan HAM RI, Badan Pembinaan Hukum Nasional, 2002.

Combs, Cindy C. Terorisme in the Twenty-First Century, Second Edition, New Jersey: Prentice Hall, Upper Saddle, River 07458, 1999.

Cronin, Audrey Kurth, Behind the Curve: Globalization and International Terrorism, International Security, Vol 27/3, Winter 2002.

Djaelani, Abdul Qadir. Memerangi Terorisme Sama Dengan Menerangi Umat Islam?, Jakarta: Yayasan Pengkajian Islam Madinah Al-Munawarah, 2002.

Folk, Richard. The Great Terror War, Gloucestershire: Arris Books, An Imprint of Arris Publishing Ltd., 2003.

Gupta, K.R. International Terrorism. Conventions, Resolutions, Legislation, Terrorist Organization and Terrorist, Volume I, Delhi: Atlantic Publishers and Distributors, 2002.

Legislation, Terrorist Organization and Terrorist, Volume II, Delhi: Atlantic Publishers and Distributors, 2002.

Juergensweyer, Mark. Terorisme Karena Membela Agama, Terror in The Hand of God, Tarawang Press, 2003.

Laqueur, Walter. The Law Terrorism Fanaticism and Arms of Mass Destruction, Phoenix: Press Paperback, 2001.

Mahmassani, Subhi. Arkan Huquq'l--Insan (Konsep Dasar Hak Asasi ManusiaStudi Perbandingan dalam Syariat Islam dan Perundang-undangan Modern), Alih Bahasa: Hasanudin, Tintamas Indonesia, Jakarta, 1993, Moch Faisal Salam, Motivasi Tindakan Terorisme, Bandung: CV. Mandar Maju, 2005.

Marpaung, Rusdi, dan Al-Araf, Terorisme, Definisi, Aksi dan Regulasi, Jakarta: Imparsial, 2003.

O.C. Kaligis \& Associates. Terorisme: Tragedi Umat Manusia, O.C. Kaligis \& Associates, Jakarta, April 2003.

Rukmini, Mien. Perlindungan Ham, Melalui Asas Praduga Tak Bersalah Dan Asas Persamaan Kedudukan Dalam Hukum Pada Sistem Peradilan Pidana Indonesia, Bandung: Alumni, 2003.

Scott, Davidson. Hak Hak Azasi Manusia, Sejarah, Teori dan Praktek dalam Pergaulan Internasional, Jakarta: PT. Pustaka Utama Grafiti, 1994. 
Hak Hak Azasi Manusia, Terjemahan A. Hadyana Pudjaatmika, Jakarta: PT. Pustaka Utama Grafiti, 1994.

Wahid, Abdul, dan kawan-kawan, Kejahatan Terorisme, Bandung: Refika Aditama, Oktober 2003.

,Sunardi, dan Muhammad Imam Sidik. Kejahatan Terorisme, Perspektif Agama, HAM, dan Hukum, Bandung: Refika Aditama, 2004.

------------------, et. al. Kejahatan Terorisme Perspektif Agama, HAM dan Hukum, Bandung: PT. Refika Aditamna, 2004.

Walker, Clive, Blackstone's Guide to the Anti Terrorism Legislation, Oxford: University Press, 2002.

Walkinson, Paul, Terrorism and The Liberal State, London: The Macmillan Press Ltd., 1977. 